\title{
AS FLORES DO MAL DOS CONTOS DE MURILO RUBIÃO
}

\section{THE FLOWERS OF EVIL IN THE TALES OF MURILO RUBIÃO}

Polyana Pires Gomes ${ }^{1}$

\begin{abstract}
Resumo: Os personagens de Murilo Rubiăo, nos contos "A casa do girassol vermelho" (1947), "A flor de vidro" (1953) e "Petúnia" (1974), sāo vítimas de opressāo inexplicável e incapazes de modificar a própria vida. A linguagem empregada nessas narrativas labirínticas é simples e concisa, o que aumenta a inverossimilhança, mas, paradoxalmente, gera uma perplexidade convincente, cabendo ao leitor interpretar os múltiplos significados sugeridos. Nesses contos, a flor - metáfora canônica da literatura - assume papel fundamental, desencadeando ou sumarizando os fatos da narrativa: um girassol vermelho, uma flor azul, petúnias e rosas pretas colaboram, assim, na estruturaçâo do fantástico e assemelham-se às flores de Charles Baudelaire (1821-1867), uma vez que revelam a angústia da ausência, da violência e da morte. Entretanto, os olhos do contista brasileiro nâo sâo como os do poeta francês, que, em As flores do mal (1857), vibram nervosamente diante da catástrofe humana, clamando por entidades rejeitadas; pelo contrário, a seriedade das situaçôes revela um narrador cético e incapaz de sorrir diante do inexplicável.
\end{abstract}

Palavras-chave: Literatura Brasileira. Conto fantástico. Murilo Rubiāo.

Abstract: Murilo Rubiâo's characters, in the tales "A casa do girassol vermelho" (1947), "A flor de vidro" (1953) and "Petúnia" (1974), are victims of inexplicable oppression and they seem unable to change their lives. The language used in these labyrinthine narratives is simple and concise, which increases the unlikelihood, but, paradoxically, creates a compelling perplexity, leaving the reader alone to interpret the multiple meanings suggested. Taking advantage of a literacy canonical metaphor, the flowers of these three tales play a key role, triggering or summarizing the narrative facts. A red sunflower, a blue flower, petunias and black roses collaborate in the structuring of the fantastic and resemble Charles Baudelaire's flowers (1821-1867), since they reveal the anguish of absence, violence and death. However, Murilo Rubiăo is not like the French poet, who in The Flowers of Evil (1857), shivers nervously before the human catastrophe, calling for rejected entities; on the contrary, the seriousness of the situation reveals a skeptic speaker that is unable to smile at the inexplicable.

Keywords: Brazilian Literature. Fantastic Tale. Murilo Rubiăo.

1 Professora de Língua Portuguesa e Literatura Brasileira do CEFET-RJ e Doutoranda em Literatura Brasileira da UFRJ.E-mail: polyanapires@hotmail.com 
Antes de Murilo Rubiăo, escritores brasileiros renomados como Machado de Assis, Lima Barreto e Humberto de Campos, por exemplo,visitaram a narrativa insólita, entretanto nenhum havia feito dela sua morada definitiva como o mineiro, primeiro dedicado exclusivamente à produçăo desse gênero.

Outro consenso, apontado por professores que se debruçaram, na década de 1980, sobre os contos de Rubiăo - Elódia Xavier, em 0 conto brasileiro e sua trajetória (A modalidade urbana dos anos 20 aos anos 70), e Davi Arrigucci, em "Minas, assombros e anedotas" -, é a unidade temática e estrutural de sua obra. Os assuntos que mais lhe interessavam podem ser percebidos a partir das seçôes temáticas que organizam $O$ ex-mágico (1947), seu livro de estreia: "Arco-íris", "Mulheres", "Montanha", "Condenados" e "Família". Nas situaçóes relatadas, os personagens sâo aprisionados em realidades indesejadas e inescapáveis, e o elemento opressor varia, podendo ser a morte, a magia, o relacionamento afetivo, a burocracia etc. Se protagonizassem um conto de fadas, saberíamos que, no final da história, o bem-estar seria recuperado, e os inocentes recompensados. Entretanto, năo é esse o destino do elenco de "A Casa do Girassol Vermelho", "A flor de vidro" e "Petúnia", contos analisados neste ensaio: além de as circunstâncias suportadas serem inusitadas, tensas e nâo esclarecidas, o desfecho năo é consolador. Os textos também se afastam das narrativas maravilhosas porque năo ensinam uma moral específica e porque inserem o evento estranho numa realidade convencional. Já nos contos de fadas, a esfera irreal preenche todo o texto, conforme as consideraçôes de Émile Schub-Koch, em Contribuiçâo para o estudo do fantástico no romance (cf. Bastos, 2010, p. 35).

Năo só o primeiro livro de Rubiăo apresenta essa construçâo narrativa; os publicados depois prezam também pela coesấo. Ao lado de poucos textos inéditos, Rubiâo republicava contos antigos com algumas modificaçôes. Para Arrigucci Jr., tal estratégia estava intimamente ligada a um assunto caro ao escritor, a metamorfose: tal como alguns personagens se transformavam a todo tempo (como Petúnia e suas filhas, ora flores, ora mulheres), seus contos também ganharam alteraçôes. Acrescentamos que a utilizaçăo de nome idêntico para personagens diferentes (como Marialice, Petúnia e Godofredo) estabelece uma conexăo esquisita dentro da obra; além das mutaçôes dentro do conto, o personagem pode migrar para outro, assumindo novo papel. Essa instabilidade dos personagens e da própria escrita indica, para Arrigucci Jr., "a questăo mais profunda da identidade năo fixada" (1987, p. 151), o que justifica parcialmente a submissâo dos seres a um destino pré-estabelecido.

A linguagem empregada para expressara cadeia de fatos inacreditáveis é simples e concisa, o que gera perplexidade - como algo estranho pode ser relatado sendo tâo banal? - e aumenta a carga de inverossimilhança da narrativa. Em relaçâo aos desafios relacionados à produçáo do gênero fantástico, em entrevista a Elizabeth Lowe, Rubiâo sugere como consegue que suas narrativas finjam naturalidade ao apresentarem eventos extraordinários: "o escritor tem primeiro é que conviver com o mistério. Depois de certa convivência, ele passa a tratar o suprarreal como se fosse a realidade. Se ele cai na fantasia, no fantástico gratuito, ele năo consegue impor o seu mistério" (1978, p. 28). Parece-nos, entăo, que o escritor contagia o narrador, que também nâo hesita diante dos fatos inexplicáveis; essa convivência banal com o insólito é comentada por Arrigucci Jr.: 
A falta de espanto mostra que ele [o narrador] se identifica com as regras de seu universo, como um ser que se submete às leis da organizaçáo a que pertence, sem ter participado de sua elaboraçăo e sem acesso aos fins a que se destina. (...) Embora lúcido, sua consciência está tolhida, como sua capacidade de açăo efetiva: nâo é sujeito da História. (1987, p. 149)

Caberia, entăo, aos leitores a hesitaçâo, efeito essencial do fantástico, de acordo com Tzvetan Todorov, que, na década de 1970, no clássico Introduçâo à literatura fantástica, afirmou: "o fantástico é a hesitaçâo experimentada por um ser que só conhece as leis naturais, face a um acontecimento aparentemente sobrenatural" (apud Bastos, 2010, p. 32). Para Elódia Xavier, essa dúvida entre realidade e ficçăo multiplicaria as possibilidades de interpretaçâo da narrativa.

Entretanto, o vínculo entre fantástico e hesitaçăo vem sendo debatido. Filipe Furtado, em A construçâo do fantástico na narrativa (1980), recorda que muitos leitores também hesitam diante de livros nâo fantásticos. Rubiāo, na entrevista citada acima, também sugere que a definiçâo estruturalista de Todorov pode ser discutida:

O fantástico em nosso século, cujo maior precursor é Kafka, e aqui no Brasil é Machado de Assis, é muito diferente daquele do século dezenove. No século passado, o fantástico era mais trágico e sombrio, como vemos nos contos de Edgar Allan Poe ou de Hoffman. Hoje nós năo temos a mesma relutância em aceitar o fantástico que teve o leitor do século passado. Aquele sempre pensava que havia no fundo um certo realismo, que o fantástico năo era uma irrealidade completa. No fantástico moderno há uma necessidade do escritor impor a sua irrealidade como se fosse real a ponto de o leitor, terminando a leitura, ficar numa certa dúvida se a realidade em que vive năo será falsa, e se a realidade verdadeira nâo será aquela da ficçăo. Os tempos, a história, obrigam o escritor a tomar uma posiçấo diferente daquela dos séculos anteriores. Năo caberiam mais os contos de fadas, o fantástico sombrio, porque o leitor moderno năo os aceitaria (...). (LOWE, 1978, p. 30)

Se a hesitaçăo do leitor náo é ponto convergente entre aqueles devotados à literatura fantástica, a quebra da causalidade - que aumenta a carga de terror, entregando o personagem e o leitor ao desconhecido -, praticada pelo gênero no século XX, é compreendida como elemento essencial à narrativa insólita por vários estudiosos brasileiros, dentre eles Arrigucci Jr., Xavier e Bastos:

a causalidade, esse componente indispensável à verossimilhança, foi atacado de frente pelos realismos irrealistas do século XX, todos empenhados em colocar em primeiro plano o insólito, que, por definiçăo, dificulta ao observador determinar as causas de que decorrem tais e tais consequências. (...) Com isso provocam efeito comumente mais aterrador que o produzido pelo sobrenatural antigo, pois o desconhecimento da instância determinadora da natureza dos acontecimentos insólitos deixa o homem na escuridăo de uma trajetória existencial sobre a qual năo tem qualquer domínio, por vezes até, nenhuma ingerência. (BASTOS, 2013, p. 4-5)

Como os protagonistas dos contos de Murilo Rubiăo năo conseguem se evadir da realidade ficcional, Xavier o distingue do herói romântico do século XIX, embora também os aproxime uma vez que assumem papel de antagonistas contra a sociedade (cf. 1987, p. 86). Concordamos que Rubiâo se afasta da estética romântica, uma vez que o narrador năo condecora o personagem herói, e, sim, o condena a uma vida sem sentido. Deste modo, a imparcialidade narrativa - nâo há nem comiseraçăo nem indiferença em 
relaçăo ao personagem oprimido - assemelha o narrador murilianoao realista.

A obra do autor é associada frequentemente à prosa machadiana, como lemos no posfácio de Vera Lúcia Andrade, "As metamorfoses de Rubiăo", que integra os Contos reunidos: "o texto despojado, sóbrio, elegante, e (...) a ironia amarga" (1999, p. 276) seriam uma "dívida literária" do mineiro em relaçăo ao carioca. Ora, aproveitamos a semântica financeira para relacionar "Memórias do contabilista Pedro Inácio", de 0 ex-mágico (1947), a Memórias póstumas de Brás Cubas (1881): o conto é o único cuja epígrafe nâo foi retirada da Bíblia: "Marcela amou-me durante quinze meses e onze contos de réis". Ratificando a intertextualidade, a ironia do narrador personagem se manifesta logo nas primeiras linhas: "O amor de Jandira me custou sessenta mil-réis de bonde, quarenta de correspondência, setenta de aspirina e dois anos de completo alheamento ao mundo" (Rubiăo, 1999, p. 105). Podemos dizer, entăo, que Rubiăo paga a dívida, embora nâo deixe de inserir seu estilo, totalmente atrelado à visăo de mundo que defende. Comparando os itens relacionados ao amor das mulheres em questâo, notam-se, no texto do século XX, o excesso de imagens relativas aos prejuízos provocados pelas moças e uma açăo estranha, pois é investigada, a partir do livro-caixa do contabilista, a origem de sua "coita d'amor". Assim, podemos assemelhar as narrativas de Rubiâo e de Machado até certo ponto, porque náo cabem, nos limites da escola realista, o exagero e a falta de causalidade. Por isso, Arrigucci Jr. recorda que todas as vezes que o realismo do século XIX se inclinou para o polo da fantasia, "esta sempre foi corrigida pelo costeio do real" (1987, p. 142); prefere, entăo, associar Rubiâo aos escritores hispano-americanos - Borges, Cortázar e outros - contemporâneos a ele, à narrativa kafkaniana e, no Brasil, a Cornélio Penna e Aníbal Machado (cf. 1987, p.143).

Todavia, o insólito da narrativa de Rubiăo nos leva à crítica da realidade, e o absurdo lido, identificado aos dramas vividos, deixa de ser absurdo, o que nos faz concordar com outro Murilo,contemporâneo e conterrâneo de Rubiăo: "a existência do enigma tende a aumentar o campo da realidade" (Murilo Mendes, apud ARRIGUCCI JR., 1979, p. 182). 0 conto “D. José năo era”, do livro A estrela vermelha (1953), expressa o ponto de vista do escritor em relaçâo ao problema da "verdade". O narrador afirma explicitamente que as informaçóes colhidas sobre o personagem que intitula o conto năo sâo confiáveis, colocando em xeque até mesmo sua existência; apesar disso, as compila textualmente: a narrativa resulta inconsistente uma vez construída por todas as dúvidas que atrapalham a escrita. A intrigante "história" simboliza a dificuldade de delimitaçăo das fronteiras entre boato, mentira, realidade. Tal dúvida está presente em todos os contos de Rubiâo, os quais investigam a realidade com fatos absurdos, ilustrada na epígrafe bíblica de "Teleco, o coelhinho", publicado também na década de 1950: "Três coisas me sâo difíceis de entender, e uma quarta eu a ignoro completamente: o caminho da águia no ar, o caminho da cobra sobre a pedra, o caminho da nau no seio do mar, e o caminho do homem na sua mocidade" (Provérbios, XXX, 18-19). A instabilidade humana - metaforizada, no conto de Rubiáo, em um animal mutante -, mais do que proporcionar alegria ao dinamizar a vida, provoca confusăo e morte. Quem tenta entender em profundidade a vida - como o autor bíblico, o narrador e o personagem que cuida do coelhinho moribundo - se depara com a ausência de respostas, embora entreveja uma, pessimista: "Por mais absurdo que me parecesse, havia uma trágica sinceridade na voz deles [Teleco e Tereza]" (Rubiăo, 1999, p.150). 
Se há trinta anos Elódia Xavier apontava o pouco interesse da crítica literária pela obra muriliana, felizmente náo se pode mais dizer o mesmo. Os trabalhos sobre o autor se multiplicam, e hoje já sâo muitas as dissertaçôes e teses que investigam a polissemia dos textos fantásticos, em especial as metamorfoses sofridas pelos personagens. Neste ensaio, seguimos a vertente dos que se interessam pela estética do aprisionamento dos seres em realidades paradoxalmente pleonásticas e estéreis. Visto que todos os contos săo assim estruturados, optamos por um fio condutor que é tema canônico da literatura de todos os tempos: as flores, que assumem papel fundamental em alguns contos de Rubiăo.

Por exemplo, em "Aglaia" e "Botăo-de-Rosa", ambos da década de 1970, as flores que nomeiam os protagonistas intitulam os contos, mais para metaforizar sua capacidade de procriaçăo do que para lhes realçar a beleza. Ambos sâo afligidos pelo excesso de vida: Aglaia engravida a todo instante, năo havendo controle anticonceptivo que refreie as gravidezes, e os filhos nascem prematura e infinitamente, o que causa o fim de seu casamento; já Botăo-de-Rosa é acusado e preso por engravidar todas as mulheres da cidade - crianças, adolescentes, adultas e idosas -, sendo condenado à morte. Já os contos analisados a seguir - "A casa do girassol vermelho" (1947), "A flor de vidro" (1953) e "Petúnia" (1974) -, conferem ao elemento natural maior relevo; mais do que nomear personagens, nesses três textos, as flores săo parte integrante da narrativa: sua presença desencadeia ou sumariza os fatos, sempre dramáticos.

Metáfora de todos os tempos, na literatura e na arte em geral (basta lembrarmos do poema "Flor de maio", de Carlos Drummond de Andrade, e dos girassóis de Van Gogh), as flores nos contos de Rubiâo nâo simbolizam uma beleza padrăo, agradável ao olhos mais sensíveis, nem anunciam amor e paz; pelo contrário, elas fogem ao lugar-comum que lhes foi oferecido especialmente no primeiro romantismo. Um girassol vermelho, uma flor azul, petúnias e rosas pretas colaboram na estruturaçăo do insólito e revelam emoçōes angustiosas como a ausência, a violência e a morte.

Assim, esclarece-se a aproximaçăo lançada no título do ensaio: como as flores de Charles Baudelaire (1821-1867) representaram pulsóes humanas marginalizadas, como o ódio, a lascívia e o spleen, e figuras rechaçadas pela sociedade, como os doentes, os pobres, os loucos, os ébrios e os imorais, as de Murilo Rubiăo traduzem pessimistamente as dores do homem moderno. Entretanto, os olhos do contista brasileiro, nos textos a seguir, náo sâo como os do poeta francês de As flores do mal (1857), vidrados e irônicos, que gargalham nervosamente diante da catástrofe humana, clamando por Sată e outras entidades rejeitadas; a seriedade das situaçóes oferecidas nos contos publicados no decorrer de três décadas do século XX revela um narrador cético e incapaz de sorrir diante do inexplicável.

\section{A CASA DO GIRASSOL VERMELHO}

Os eventos dramáticos ocorridos em torno da Casa do Girassol Vermelho, localizada longe "da cidade e do mundo" (RUBIÂO, 1999, p. 16), sâo contados por um de seus moradores, Surubi, que, junto com os demais, comemora a morte de Simeâo, rígido padrasto que os submetera a proibiçóes e violências. O regozijo transcorre nos lindos jardins que circulam a casa ou nas margens de represa próxima, e năo no interior da 
Casa, metonímia do dono falecido. Além disso, a localizaçăo isolada da Casa e outras características que apontaremos a seguir aproximam-na às habitaçóes dos contos de fadas.

Seis jovens a habitam: os irmáos Xixiu, Belinha e Marialice, apresentados de maneira estereotipada - Xixiu é bruto, Belinha, sensual, e Marialice, "etérea" - e outro grupo de irmáos, Belsie, Nanico e Surubi, menos expressivos, parceiros amorosos daqueles: Xixiu namora Belsie; Belinha, Nanico, e Marialice, Surubi. Cabem aos homens as açóes efetivas da história - Xixiu é o líder do grupo; Surubi, o narrador, e Simeâo, o antagonista -, apenas Belinha se destaca na ala feminina, mas, como veremos, de maneira negativa.

Depois da duradoura temporada ditatorial do padrasto, os jovens se sentem livres para aproveitar a vida, especialmente o sexo, antes impossível, uma vez que Simeăo proibira qualquer aproximaçáo. A nova situaçáo leva-os a uma espécie de transe; desesperados, lançam-se a tudo o que antes năo lhes era permitido. Belinha sugere a troca de parceiros, e substitui Nanico por Surubi, deixando aquele com Marialice. Entretanto, há um personagem cujo impulso sexual nâo é libertado: os acontecimentos levam ao florescimento da violência de Xixiu, que parece incorporar a arrogância do antigo carrasco. Entretanto, atendendo aos pedidos dos companheiros, o líder faz concessôes e se entrega, parcialmente, aos festejos, aceitando, por exemplo, tomar banho na represa. 0 caminho da Casa à represa simboliza a saída do ambiente de encarceramento e esterilidade para a entrada no local de vida, onde Belinha engravidará.

Enquanto os outros casais namoram, Xixiu năo abre măo da moral castradora e os repreende rispidamente: "Se o velho Simeâo estivesse vivo sairia tiro!" (RUBIÂO, 1999, p. 17).Apesar de sentir medo das palavras do irmáo, a alegria faz com que Belinha se lance a Surubi, se "derramando ferozmente" (RUBIĀO, 1999, p. 17). Năo só ela: "Todos nós fôramos tocados por uma centelha diabólica, que nos fazia buscar, ansiosos, no prazer, o esquecimento dos dias de desespero do passado" (RUBIÂO, 1999, p. 17). Contudo, Xixiu entra numa espécie de alucinaçăo, grita xingamentos contra Simeâo, se embrenha mata adentro e, para o desespero dos outros, năo retorna.

Nesse ponto, o narrador, por meio de flashback, nos esclarece parcialmente a tensăo estabelecida, recordando como eles haviam se tornado "filhos adotivos" de Simeâo. Quem os havia resgatado da fome fora D. Belisária, sua esposa, que, enquanto viva,os defendia da fúria do marido. Nâo fica claro como ela conhecera as crianças nem por que Simeăo sentia tanta raiva das traquinagens. Com a morte da mulher, o "homem de moral rígida" (Rubiăo, 1999, p. 19) proíbe a conversa entre os jovens e, quando flagra Xixiu conversando com Belsie, obriga-os ao casamento, embora mantenha a proibiçáo de nâo se tocarem. Às vezes a repressâo desencadeava brigas ferozes, especialmente entre Simeăo e Xixiu e, quando a vitória era do mais jovem, os irmăos festejavam dançando, o que nos remete às cantigas medievais relacionadas às lutas entre guerreiro se às histórias de fadas (pela maneira estereotipada de apresentar as (re)açóes dos personagens). Mas a vingança de Simeâo sempre era violenta, e os rapazes viviam tramando algo contra ele. Quebrando as expectativas, o vilăo morre subitamente do coraçáo. Os jovens fazem um velório nada convencional: deixam o corpo no jardim, colocam uma rosa vermelha em sua boca e cospem-lhe o rosto. Depois, surram os capangas do finado: "Pisávamos na memória do velho Simeâo, escarrando no passado" (RUBIÂO, 1999, p. 21). 
Ora, a história de ódio justifica o misto de euforia e terror do grupo: se, por um lado, há o desejo desenfreado por novos prazeres, por outro, a morte de Simeăo desestrutura a Casa e passa a assombrá-la. Tal como se fosse um deus, ele os vigiava e, a qualquer momento, os puniria. Por isso, os jovens acreditam que o desaparecimento de Xixiu está associado a Simeâo e encerram a comemoraçâo: a noite chega fragmentando o dia (cf. RUBIÂO, 1999, p. 21), ou seja, a euforia dá lugar à preocupaçăo. Convictos de que o irmăo fora continuar a briga com o velho, reconhecem a heroicidade de Xixiu: "Quem soltaria os estilhaços e nos convidaria para os assaltos decisivos, os grandes gritos de revolta?" (RUBIÂO, 1999, p. 23). Chegam à conclusăo de que sem a violência de Simeâo e a rebeldia de Xixiu "nada mais seria importante, digno da violência, da paixăo" (RUBIĂO, 1999, p. 23). Mais uma vez reforça-se a ideia de que a Casa do Girassol Vermelho sobrevivia graças a uma força destrutiva e sedutora. Seu nome, sempre grafado de maiúscula, a distingue e personifica, revelando um papel narrativo muito maior do que aquele de abrigar os protagonistas, aproximando-a às casas amaldiçoadas dos contos de terror.

Conscientes de que, com a ausência dos homens violentos, que sustentavam a Casa, ela "se dobraria sobre as próprias ruínas" (RUBIĀO, 1999, p. 23), os jovens decidem partir, tentando, dessa forma, reagir "contra a sombra do velho Simeâo" (RUBIÂO, 1999, p. 23). Apenas Surubi apresenta ânimo necessário para năo sucumbir junto com a Casa; entretanto, os outros, apáticos, o seguem. A frase dita por ele na cena final - "Este foi o último dia" (RUBIÂO, 1999, p. 24) - pode indicar esperança (como se acreditasse que, saindo da Casa, teriam vida nova), como pessimismo (como se longe da Casa nâo conseguissem sobreviver). Em resposta, Belinha lança os olhos desanimados para o alto e para baixo, mostrando o girassol vermelho que surgia em seu ventre. Ambíguo também é o aparecimento dessa flor: marca a perpetuidade da violência, pois o grupo levaria o Girassol Vermelho, ou seja, a Casa, aonde fosse? ou representa esperança de vida nova longe da Casa, uma vez que a gravidez foi fruto de momento de liberdade e prazer? Como nos explica Bastos, no gênero fantástico,"permanece o fundo comum de uma ambivalência quanto à natureza do acontecimento insólito, especialmente por conta da elisấo, completa ou parcial, da causalidade" (BASTOS, 2015, p. 37). Apoiados na proposta pessimista da obra de Rubiăo como um todo e na repetiçăo do fenômeno fantástico (o florescimento vegetal no ventre de mulheres) em "Petúnia", concretizando o mal, somos levados a escolher a primeira interpretaçâo.

No livro de estreia, Rubiăo seleciona o girassol, flor natural da América do Norte, desde muito utilizada pelos indígenas como alimento, por simbolizar a fertilidade e por ser planta heliotrópica (o caule posiciona a flor na direçăo do sol): nomeia a Casa e vincula eternamente os jovens à violência sofrida. O escritor transforma em negativo o signo luminoso: aonde quer que fossem, os personagens seriam, sempre, atraídos pela açăo devastadora e negativa; além disso, a "gravidez" de Belinha năo é sinal de fecundidade, mas,sim,comprova o círculo vicioso, o cordăo umbilical maldito, que os prende definitivamente à Casa do desamor.A agressividade da narrativa pode justificar a escolha do girassol vermelho, e năo do amarelo, mais comum. As cores, em Murilo Rubiâo, representam, em geral, as emoçôes, como os olhos do velho de "A armadilha", de onde "emergia uma penosa tonalidade azul" (RUBIÂO, 1999, p. 154) ou como as múltiplas de "O pirotécnico Zacarias": "A princípio foi azul, depois verde, amarelo e negro. Um negro espesso, cheio de listras vermelhas, de um vermelho compacto, semelhante a densas fitas de sangue. Sangue pastoso, com pigmentos amarelados, de um amarelo 
esverdeado, quase sem cor. Sem cor jamais quis viver. Viver, cansar bem os músculos, andando pelas ruas cheias de gente, ausentes de homens" (RUBIĂO, 1999, p. 28).

A Casa que os resgatou da penúria e os abrigou em dias violentos, lança os jovens para fora, mas năo sem marcá-los, para que nunca esqueçam o que se passou lá. Nesse sentido, a epígrafe bíblica - "vós sois o sal da terra" - é irônica, visto que a atitude do grupo nâo é exemplar e evangélica, bem porque eles "salgam" a terra com suas desilusôes e traumas, bem diferente do "sal" evangélico, que promete descorromper a humanidade.

\section{A FLOR DE VIDRO}

O conto trata da ausência, e a flor, agora, além de símbolo, é a causa dos acontecimentos dramáticos vividos por Eronildes e Marialice. A epígrafe que encabeça a história, retirada do livro profético de Zacarias, anuncia a esperança de libertaçâo e de paz concretizada pela vinda do Messias, cujo símbolo é a luz. Entretanto, apenas curto período da vida do protagonista foi feliz, além de que, fisicamente, ele náo vislumbra nenhuma luminosidade, pois fica cego. Ambígua também é a materializaçăo do amor do casal, uma flor de vidro: a beleza originalmente natural e efêmera passa a ser fabricada e resistente. Se se tratasse de um amor ideal, messiânico, a durabilidade seria desejada, mas como a flor representa o sofrimento, sua extensa validade é cruel.

A "reminiscência amarga" sentida por Eronildes, morador solitário de uma cidade pequena, se refere à saudade do romance vivido, no passado, com Marialice. Uma flor de vidro o ajuda a lembrar, diariamente, da amada ausente; além disso, ele sente que ela está em todos os lugares: nos campos, na face de outras mulheres, no verniz dos móveis, nas paredes alvas, no barulho do trem. Impossibilitado de ver, o pensamento dele é tomado por imagens associadas a Marialice, criando uma realidade consoladora, pois, se ele náo via nada, mas todas as coisas estavam lá, da mesma forma, a mulher permanecia, mesmo que silenciosa.

A rotina melancólica é abalada pela repentina notícia do retorno da amada: Eronildes coloca uma venda na vista inutilizada, corta o cabelo e sai correndo pelos campos até a estaçâo de trem. Eles se encontram com emoçăo, ela o chama de "general russo", e o narrador observador elogia a jovialidade da moça de trinta anos. A correspondência ao seu amor faz com que Eronildes acredite que ela veio para ficar.

O narrador nâo esclarece porque a moça fora embora e tampouco porque voltara, criando uma situaçấo de mistério, enfatizada pela estranha resposta de Marialice à pergunta de Eronildes sobre o que ela fizera na ausência dele - "Ontem pensei muito em você" (RUBIÂO, 1999, p. 130). O narrador insinua outros relacionamentos: "Os corpos unidos, quis falar em Dagô, mas se convenceu de que năo houvera outros homens. Nem antes nem depois" (RUBIÂO, 1999, p. 130). Como nāo há sujeito explícito nesse trecho, năo sabemos se Eronildes desconfia da fidelidade da viajante ou se ela nâo quer trazer à tona outras experiências, preferindo investir em um recomeço. Apesar da ambiguidade, percebemos que prevalece o desejo de modificar o passado e moldar o futuro, para solidificar o amor redescoberto. Entretanto, o sonho ou a ironia devastadora do fantástico muriliano năo deixará que o romance flua como os amantes querem.

Depois de uma noite de amor, Eronildes dorme bem pela primeira vez desde que 
Marialice foi embora, mas, quando acorda (ou ainda estaria sonhando?) percebe que o tempo recuou doze anos e apenas ele é consciente de tal retorno. Expressóes como "seiva nova", "jovem e fresca", "algo de novo irrompia", "o sol brilhava intenso" (RUBIÂO, 1999, p. 131) marcam o rejuvenescimento do casal e do cenário, que expressa milagre semelhante ao aludido na epígrafe. A época messiânica teria chegado para Eronildes, e a luz invade sua realidade: "brilhavam-lhe os olhos e a venda negra desaparecera" (RUBIÂO, 1999, p. 131). Entretanto, sua felicidade estava depositada no passado e nâo no futuro, como creem os judeus.

O relato metafórico do momento que inaugura o fantástico- "Acordou cedo, vagando ainda nos limites do sonho" (RUBIÂO, 1999, p. 130) - nos permite ler os fatos que seguem tanto de maneira ficcional (na prosa muriliana, o tempo pode regredir), quanto de maneira realista (na verdade, tudo era um sonho), como afirma Arrigucci Jr.:"Lidando com materiais muitas vezes disparatados ou arbitrários, [a narrativa fantástica de Rubiăo] torna-se capaz de sugerir, pela transgressâo da causalidade, do tempo e do espaço ou do princípio da identidade do ser, o clima onírico" (1987, p. 146).

Nesse clima, o cotidiano dos jovens namorados é relatado: passam os dias namorando no bosque próximo da casa, ele sempre pregando sustos na moça, como quando se embrenha nas matas, se esconde para que ela o procure e ri do desespero de Marialice. Essa movimentaçăo nos recorda "A casa do Girassol Vermelho", quando Xixiu desaparece, e Belsie vai a sua procura; entretanto, agora, o desaparecimento é causa e náo consequência dos problemas: muito enraivecida, a Marialice de "A flor de vidro" roga uma praga: "Tomara que um galho lhe fure os olhos, diabo!" (RUBIÂO, 1999, p. 131), exatamente o que acontecerá com Eronildes. Para acalmá-la, ele traz da mata uma flor azul para ela e tenta beijá-la, ao que ela resiste por um tempo. O narrador nos informa que tal embate era comum: "A paz náo tardou a retornar, porque neles o amor se nutria da luta e do desespero" (RUBIÂO, 1999, p. 132).Temos aqui mais uma correspondência com a Casa, uma vez que sentimentos aflitivos e passionais constituem a base estrutural da existência dos personagens. Além disso, Rubiâo se valeu do mesmo nome para batizar personagens de contos distintos: Marialice é nome tanto da moça "etérea", insossa, da Casa do Girassol Vermelho, como da namorada que recebe a flor azul.

Tal como o girassol, a flor azul é símbolo do embate, inicialmente prazeroso para Eronildes, mas sempre incômodo para Marialice. Depois do episódio acima mencionado, todas as vezes que passeavam pela mata e viam a flor no alto de uma árvore, ele comprimia a jovem nos braços, e ela se assustava e, silenciosa, esperava uma explicaçấo. “Contudo, ele guardava para si as razôes do seu terror" (RUBIÂO, 1999, p. 132). Ora, o final da história nos sugere porque a flor, nesse retorno ao tempo, provoca medo no rapaz: consciente do futuro (ou do passado?), sabe que a praga se realizará, uma vez que a cegueira foi causada por um galho, e a flor azul se transformaria em flor de vidro. Haveria, para o personagem, alguma esperança de mudar o rumo dos acontecimentos, evitando a partida da amada e a cegueira?

Como já foi dito, Rubiăo năo proporciona a seus personagens desfechos felizes. Eronildes nada faz para reverter a sequência dos fatos, e a história náo se altera: terminadas as férias, ela vai embora e ele se fere nos galhos, ficando cego: "a presença da flor de vidro revelou-se imediatamente. (...) os trilhos, paralelos, sumindo-se ao longe, condenavam-lhe a irreparável solidăo" (RUBIÂO, 1999, p. 132). A ambiguidade perpassa 
essa narrativa labiríntica: será que lhe foi negada a possibilidade de transformaçăo ou ele que náo soube aproveitá-la? No primeiro caso, a narrativa fantástica funcionaria como um deus sombrio e irônico, que oferece ao personagem os prazeres antigos, mas năo lhe permite mudar o rumo dos acontecimentos - por exemplo, ser mais cortês e năo rir do desespero da namorada, evitando a praga - e impedir o estabelecimento da flor de vidro como símbolo da separaçăo. No segundo caso, a narrativa expressaria a incapacidade do ser humano de modificaçăo, uma vez que, dada a ele a chance de voltar no tempo e se emendar, ele é incapaz de escrever outra história. Seja qual for a chave de leitura, é evidente o olhar pessimista de Rubiâo tanto em relaçăo ao contexto opressor que impossibilita a açấo do homem quanto em relaçáo à inércia humana diante da dificuldade. Nesse sentido, confirma-se a indicaçăo de Xavier e Arrigucci, quando afirmam que o fantástico muriliano desperta o leitor para uma leitura mais profunda, num processo de conscientizaçáo inquietante: “O fantástico dá lugar ao afloramento de um real mais fundo" (Arrigucci, 1987, p. 147). Assim motivados, pensamos no que terá sido da vida de Eronildes depois do ponto final do texto: para ser coerente com a obra de Rubiâo, ele nâo teria sido libertado do passado e voltado para o futuro, ou seja, estaria preso a uma situaçăo labiríntica: depois da partida de Marialice, teria esperado mais doze anos para reencontrá-la, passar apenas uma noite com ela e, mais uma vez, voltar ao passado, repetindo para sempre o mesmo ciclo diabólico (aproveitando a etimologia da palavra, que significa separaçăo, distância).

\section{PETÚNIA}

O narrador de "Petúnia", conto publicado em 1974, também apresenta um homem aprisionado a uma realidade restrita e insólita: Éolo, casado com Cacilda, ao longo da narrativa, assume obrigaçôes advindas das mortes ocorridas em sua família. Se nos contos escritos antes da década de 1970, ainda se podia observar humor (na inocência do homem traído, em "O bom amigo Batista") ou índice pueril (como em "Teleco, o coelhinho"), nos publicados posteriormente, o tom predominante é de frustraçâo pungente, e os temas sâo adultos. Nesse sentido, muitas vezes a crítica leu as narrativas de Rubiăo como uma reaçâo ao clima de tensáo política e proibiçôes sociais desencadeadas pela ditadura militar. Embora năo haja nenhuma referencialidade explícita da situaçâo do país, seus contos permitem também essa interpretaçăo, uma vez que o sujeito é subtraído da liberdade sem saber por que e muitas vezes por quem.

Em "Petúnia", o problema central da história é a morte misteriosa das filhas do casal. Diferente dos contos anteriormente analisados, o insólito aparece desde a primeira linha: parece que os únicos personagens só humanos săo Éolo e Mineides, sua mâe, pois a mulher, também chamada de Petúnia, ora é humana, ora é flor, e suas filhas sáo flores. A origem dos nomes pode colaborar na compreensâo do emaranhado lógico: Éolo (do grego, senhor dos ventos) é aquele que fecunda Cacilda (de origem teutônica, lança de combate) que, ao que tudo indica, é quem enforca as filhas e as enterra no jardim da casa. A tragédia abate o pai, que, triste e desesperado, as desenterra todos os dias para que possam brincar com os "titeus" (seres minúsculos) e "timóteos" (flores alegres e dançarinas). Faz isso escondido da mulher, que năo gostava dos amigos das petúnias, porque eles as despetalavam, deixando-as nuas. 
Para que a trama possa ser melhor compreendida, depois de apresentar o drama principal, o narrador utiliza a estratégia do flashback que, como já vimos, é técnica recorrente em Murilo. Em "Petúnia", descobrimos que, num tempo pretérito, Éolo nâo se interessava por ninguém (era "enfastiado" (RUBIÂO, 1999, p. 181), como muitos personagens de Rubiâo) e năo queria se casa; é a mâe, preocupada com a posteridade, que lhe arranja Cacilda. A figura materna exerce poder sobre ele, e a maneira como ela o chama ("Éolinho") o aborrece porque, mais do que afetuosidade, expressa superioridade. Ele acaba por gostar da candidata, e a máe morre antes do casamento, pedindo que ele coloque uma tela com a imagem dela no quarto de casal. $O$ filho reage negativamente, aparentando saber as consequências da realizaçăo da última vontade da mâe, mas Cacilda cede à solicitaçăo de Mineides. Entretanto, um dia, a maquiagem do quadro derrete, e o filho passa a retocá-la diariamente, aceitando o fato como se fosse uma obrigaçăo, o que enlouquece a mulher, que năo consegue mais se relacionar amorosamente com ele.

Quando as três filhas aparecem estranguladas, Cacilda coloca a culpa na sogra morta e proíbe que o marido vá ao jardim. Esse impedimento é típico das narrativas de Rubiâo, que encerra vários personagens dentro da própria casa, como o homem detido no apartamento suspenso de "O bloqueio", conto da mesma época que "Petúnia". Aqui, a mulher coloca cavalos-marinhos para evitar a saída de Éolo, além de trancá-lo no quarto. Entretanto, toda noite, ele ultrapassa os obstáculos e desenterra as filhas-flores para que elas se divirtam, o que passa a ser outra tarefa, mas bem diferente da última que recairá sobre ele, bem porque desta ele năo será vítima, mas o agente.

Certa noite, Éolo descobre rosas pretas nascendo da barriga da mulher, se desespera e começa a cortá-las; como o fenômeno ocorre todas as noites, ele ganha mais essa tarefa diária. Angustiado com as obrigaçóes desgastantes, um dia "enterra" a flor em Cacilda, matando-a e causando uma proliferaçâo pior: mesmo depois de enterrá-la no jardim, rosas pretas crescem assustadoramente dentro e fora da casa. Confirma-se, assim, a epígrafe bíblica que introduz a narrativa: "E nascerăo nas suas casas espinhos e urtigas e nas fortalezas o azevinho" (Isaías, 34: 13). Para que a praga náo ultrapasse os limites da casa, e os vizinhos o denunciem, ele corta flores o dia inteiro: "Năo dorme. Sabe que os seus dias seráo consumidos em desenterrar as filhas, retocar o quadro, arrancar as flores. Traz o rosto constantemente alagado pelo suor, o corpo dolorido, os olhos vermelhos, queimando. O sono é quase invencível, mas prossegue" (RUBIÂO, 1999, p. 186).

As obrigaçōes a que Éolo se prende se relacionam à vida (a "manutençâo" da mâe e a "ressurreiçăo" das filhas) e à morte (a poda das flores). O papel desempenhado pelas mulheres na narrativa, mais do que produzir vida como as plantas (Mineides e Petúnia săo máes), é ocasionar morte: Mineides "condena" o casal à infelicidade, e Petúnia mata as filhas, gerando excessivas rosas pretas; e todas contribuem para o aprisionamento de Éolo. De fato, as personagens femininas, em Murilo Rubiâo - Belinha ("A Casa do Girassol Vermelho"), Marialice ("A flor de vidro") e Mineides e Petúnia - săo, em geral, responsáveis pelos acontecimentos destrutivos que assolam os protagonistas, na maioria das vezes, do gênero masculino.

Os acontecimentos inexplicáveis nos levam à formulaçăo de perguntas muito semelhantes àquelas feitas pelos homens de todos os tempos: por que Eólio sofre tanto? 
por que realmente Cacilda enlouquece? As perguntas lançadas implicitamente săo as mesmas que os religiosos fazem a Deus. Nem as máximas religiosas que abrem as histórias de Rubiăo oferecem um sopro de esperança aos personagens. Nesse sentido, nâo há lógica que interprete a vida, e esta sempre é dramaticamente encerrada (seja com a morte, seja com a prisâo do homem numa realidade sufocante e triste).

\section{FECUNDIDADE NOCIVA}

Davi Arrigucci Jr. finaliza o ensaio dedicado a Murilo Rubiăo afirmando que o texto crítico sobre sua obra fantástica resultou repetitivo, embora tenha o retocado mais de uma vez. O professor sugere, assim, que a crítica imitaria, de certa forma, a arte: ao tratar da redundância, dos eventos labirínticos e de excesso típicos da narrativa muriliana,o ensaísta se enreda no mesmo procedimento circular. Passando pela mesma experiência, ratificamos o desabafo do ensaísta, acrescentando que a linguagem concisa e objetiva do contista se torna, nesse sentido, ainda mais louvável e invejável.

A obra de Rubiăo também é econômica - compôs um pouco mais de três dezenas de contos - e como quantidade năo é qualidade, o escritor é cada vez mais aplaudido por inaugurar consistentemente a literatura fantástica no Brasil. Restrita também, como observamos, é a liberdade dada aos personagens, vítimas de uma opressăo inexplicável (representada pelos excessos) e incapazes de modificar o rumo da própria vida (o que os limita a uma existência sem progressâo). Da realidade fantástica criada pelas narrativas, espécie de labirinto problemático, o escape só se dá, quando isso ocorre, com a morte. Por isso Xavier chama atençăo para o estabelecimento do infinito nos contos de Murilo, o que Arrigucci chama de "círculo fantástico": "curiosamente, o movimento é contínuo, mas nâo progride; multiplica-se, repisando a unidade" (ARRIGUCCI JR., 1987, p. 151).

O círculo fantástico potencializa o sofrimento, como se ao homem só coubessem a intriga, a falta de comunicaçăo, o ódio, o desamor, a violência, a corrupçăo, a mentira. Como as personagens de Rubiăo năo săo donas do seu destino, năo conseguem escapar das situaçôes extremas de afliçăo e de desorientaçăo. O que as oprime pode ser vislumbrado nas epígrafes bíblicas - nas quais a lógica da vida é submetida ao elemento sobrenatural e onipotente -, nas leis naturais e sobrenaturais incontroláveis - como, por exemplo, as mutaçōes das Petúnias -, nas relaçôes sociais injustas e nos relacionamentos interpessoais problemáticos - como vimos na Casa do Girassol Vermelho.

A relaçăo entre gêneros é sempre complicada nos contos de Rubiăo. O amor nâo faz parte do presente dos personagens, só aparece nos relatos em flashback, quando os amantes fruíam de sua alegria. Ademais, os frutos do relacionamento amoroso simbolizados pelas flores - sâo tristeza e solidáo causadas, predominantemente, pela brutalidade do homem (Simeâo, Xixiu, Eronildes, Éolo) e pela inconstância da mulher (Belinha, Marialice e Petúnia). Como năo conseguem se relacionar bem, a soluçăo é o desaparecimento ou a morte.

As estratégias empregadas pelo contista podem ser comparadas àquelas utilizadas na construçăo infinita do "Edifício", como afirmava o personagem catedrático da Faculdade de Engenharia reticente com o projeto do prédio, cujo plano parecia basear-se em "vagas experiências de outra escola de concretagem" (RUBIÂO, 1999, p. 159) 
que năo a convencional. Certamente, o fantástico nos contos murilianos exige do leitor muita atençáo para compreender a realidade sobre a qual o narrador se refere implicitamente. A multiplicidade de sentidos própria da literatura é, entăo, potencializada, tal como os dados hiperbólicos oferecidos na maioria das histórias, que apresentam conjunturas muito semelhantes às enfrentadas pelo homem moderno. Nesse sentido, os contos de Rubiăo podem estimular a interpretaçăo e o enfrentamento dos absurdos cotidianos, ficcionais e extratextuais, aos quais somos submetidos diariamente.

\section{REFERÊNCIAS}

ANDRADE, Vera Lúcia. As metamorfoses de Rubiăo. In: RUBIÂO, Murilo. Contos reunidos. $2^{a}$ ed. Sáo Paulo: Ática, 1999.

ARRIGUCCI JR., Davi. Minas, assombros e anedotas (os contos fantásticos de Murilo Rubiăo). In:

Enigma e comentário - ensaios sobre literatura e experiência. Sâo Paulo: Companhia das Letras, 1987.

. A noite de Cruz e Sousa. In: . Achados e perdidos. Săo Paulo: Companhia das Letras, 1979.

BASTOS, Alcmeno. Murilo Rubiăo e a questăo da causalidade. In: BATALHA, Maria Cristina;

GARCÍA, Flavio (Orgs.). Murilo Rubiâo 20 anos depois de sua morte. Rio de Janeiro: EdUERJ, 2013.

. Os realismos irrealistas na literatura brasileira contemporânea. Disponível em http://www.alcmeno.com/wordpress/wp-content/arquivos/os-realismos-irrealistas-2010-sem-adendos.pdf. Acesso em: 03 dez. 2015.

LOWE, Elizabeth. Entrevista con Murilo Rubiăo. Chasqui: revista de literatura lationamericana. Arizona (EUA), v. 7, n. 3, p. 24-33, 1978.

RUBIÂO, Murilo. Contos reunidos. 2a ed. São Paulo: Ática, 1999.

XAVIER, Elódia. 0 conto brasileiro e sua trajetória: a modalidade urbana dos anos 20 aos anos 70. Rio de Janeiro: Padrăo, 1987.

Submetido em 04 de março de 2018

Aceito em 16 de julho de 2018 